\title{
The Effect of Reputation and Academic Service Quality Toward Student Satisfaction
}

\author{
Sudiharto $^{1}$, Rosita Anggraini' ${ }^{2}$, Irwansyah $^{3}$ \\ ${ }^{1}$ Graduate student Communication Science Postgraduate Program (STIKOM), Indonesia \\ ${ }^{2}$ Posgraduate Interstudi, Indonesia \\ ${ }^{3}$ Communication Science Faculty of Sosial Science, University of Indonesia, Indonesia \\ Corresponding Author's Email: sudiharto7@gmail.com
}

\begin{abstract}
This study aims to determine and explain the effect of reputation and academic service quality on student satisfaction, at the Interstudi Design College (STDI) in Jakarta. This type of research is explanatory research with a quantitative approach. For reputation with Charles J. Fomburn corporate reputation theory. Measuring service quality according to the theory of Parasuraman \& Zeithaml (2012). Continuing customer satisfaction students with the theory of Parasuraman $\&$ Zeithaml (2012). The research was conducted at The Interstudi Design College (STDI) with a population of all active student the semester totaling 500 students. Distribution of samples by distributing questionnaires to selected students as primary data and Interviews with STDI leaders. Where as secondary data with literature. The number of samples with the Slovin formula, and the stratifield random sampling method. Technical analysis of data using multiple linier regression. Thus research resulted that. Firstly, Significant effect between reputation on STDI student satisfaction, Secondly, Significant effect between academic service quality on STDI student satisfaction. Thirdly Significant effect between reputation and academic service quality together towards STDI student satisfaction. Reputation must always be maintained and the quality of academic services also so that students get satisfaction. The level of satisfaction students of educational service users is a measure of the success of higher education institution in managing it. So that it is expected to increase the total new students STDI.
\end{abstract}

Keywords: reputation, academic service quality, student satisfaction

\section{INTRODUCTION}

The level of intense competition between private universities in Jakarta requires university management to be asked to maintain a good reputation, good academic service quality so that student satisfaction can be achieved. Student satisfaction can be a benchmark for good university management, as well as other factors. To make intelligent people through education, because education is the cutting edge. The government has tried to prioritize development in the education sector to achieve quality and productive human resources. Higher education institutions have the task not only to produce graduates, both in quantity but also 
quality and ready to be a motivator, innovator and dynamicator of various types of levels of expertise to encourage national development (Yudana, Natajaya, 2013).

Various methods are used by the College to get a positive reputation and students get satisfying services. Interstudi Design College (STDI) is one of the private tertiary institutions in Jakarta. Under the Interstudi Education Foundation, it was established in 1997 under a decree Ministry of National Education c.q. Director General of Higher Education No. 7 / DO / 2007 dated January 4, 2007. As a college operational license. With the operational permit and STDI law, it officially began operating in carrying out its function as a higher education institution managed by a non-governmental institution. The establishment of STDI is the answer for the community to get quality education in the field of design at an affordable cost. The quality of education must continue to take precedence over its achievements, and are demanded to maintain the reputation and quality of academic services so that students get satisfying services. If the level of satisfaction meets student expectations, the institution's reputation has a positive value in the present and future. Besides the quality of academic services as part of public services must also focus in accordance with student expectations. Meeting the expectations for the reputation and quality of academic services is the main goal of public services, so quality resources are needed. Higher Education Institutions are required to maintain the quality of education through recognition from the National Accreditation Board (BAN).

Table 1. Accreditation of Higher Education Study Programs.

\begin{tabular}{|c|c|c|c|c|c|}
\hline College & Study program & Level & $\begin{array}{l}\text { The } \\
\text { region }\end{array}$ & Decree number & Year decree \\
\hline $\begin{array}{l}\text { Interstudi } \\
\text { Design } \\
\text { College }\end{array}$ & Product Design & S1 & & $3 \begin{array}{l}\text { 2705/SK/BAN- } \\
\text { PT/Akred/S/XI/2016 }\end{array}$ & 2016 \\
\hline $\begin{array}{l}\text { Interstudi } \\
\text { Design } \\
\text { College }\end{array}$ & $\begin{array}{l}\text { Visual } \\
\text { communication } \\
\text { design }\end{array}$ & S1 & & $3 \begin{array}{l}2706 / S K / B A N- \\
\text { PT/Akred/S/XI/2016 }\end{array}$ & 2016 \\
\hline $\begin{array}{l}\text { Interstudi } \\
\text { Design } \\
\text { College }\end{array}$ & Design interior & S1 & & $3^{3207 / \mathrm{SK} / \mathrm{BAN}-}$ & 2016 \\
\hline
\end{tabular}

Source : BAN PT 2019 (https://banpt.or.id/direktori/institusi/pencarian_institusi.php

Educational activities are not only oriented towards the end result but must prioritize higher education accountability. Good accountability includes quality assurance, quality control, quality improvement. Accountability is the demand of a college that can be accountable to the public (Permenristekdikti No.61 of 2016 concerning the Internal Quality Assurance System). The reputation of an institution or organization is important in governance, especially in the world of higher education. Because the reputation of a good or bad institution or 
organization is an important indicator. Even though reputation is complex, but if managed well it will benefit the organization. There are various views about reputation in society. Research conducted by (Wantara, 2009) produces the effect of reputation on satisfaction is the most powerful influence. Regarding reputation, there are six elements / dimensions of namely men by $12 \%$ and women by 13.3.7\%. Meanwhile, in the Department of Interior Design, more male respondents were $9.6 \%$ and women were only $1.2 \%$ due to the greater number of male students. Furthermore, in the fashion design department, the majority of students are women, so the portion of the number of respondents taken is $3.6 \%$ male and $15.7 \%$ female. By looking at the distribution of respondents according to the proportion of the number of students by sex in each department, the sample is representative.

\begin{tabular}{lllccc}
\hline \multirow{2}{*}{ No } & \multicolumn{1}{c}{ Majors } & \multicolumn{2}{l}{ Frequency (people) } & \multicolumn{2}{l}{ Percentage (\%) } \\
\cline { 3 - 6 } & & $\mathrm{L}$ & $\mathrm{P}$ & $\mathrm{L}$ & $\mathrm{P}$ \\
\hline \multirow{2}{*}{ 1 Visual Communication Design } & 20 & 18 & 22.9 & 21.7 \\
2 Multimedia Design & 10 & 11 & 12.0 & 13.3 \\
3 Interior Design & 8 & 1 & 9.6 & 1.2 \\
4 Fashion design & 3 & 13 & 3.6 & 15.7 \\
Amount & 40 & 43 & 48.2 & 51.8 \\
\hline
\end{tabular}

Table 2. Distribution of Respondents' Identities

\section{Testing the Classical Assumptions of the Multiple Regression Model}

The classic assumption test of multiple linear regression models is performed on the error of the regression model to test normality, nonheteroscedasticity and multicollinearity. First, the normality test results show the value of sig. $=0.057>0.05$, then don't reject $\mathrm{H} 0$. That is, the error of the regression model spread normally. Secondly, the test of non-heteroscedasticity using the graphical method is to plot between dependent variables on the horizontal axis and standard residuals on the vertical axis. The plot shows not to form a certain pattern, this indicates the regression model has a homogeneous error. Third, the multicollinearity test shows a Variance Influence Factor (VIF) value of 2.90 (Table 4) which is smaller than 10, then does not reject H0. That is, there is no correlation between independent variables. Thus, it can be concluded that there was no violation of the classical assumptions of the regression model error. 


\section{Estimation and Testing of Regression Coefficients}

The results of the calculation of estimation and testing of the regression coefficients are listed in Table 4, the regression model constructed is:

$$
\begin{gathered}
Y=1.186+0.230 X_{1}+0.306 X_{2} \text { atau } \\
Y=0.230 X_{1}+0.306 X_{2}
\end{gathered}
$$

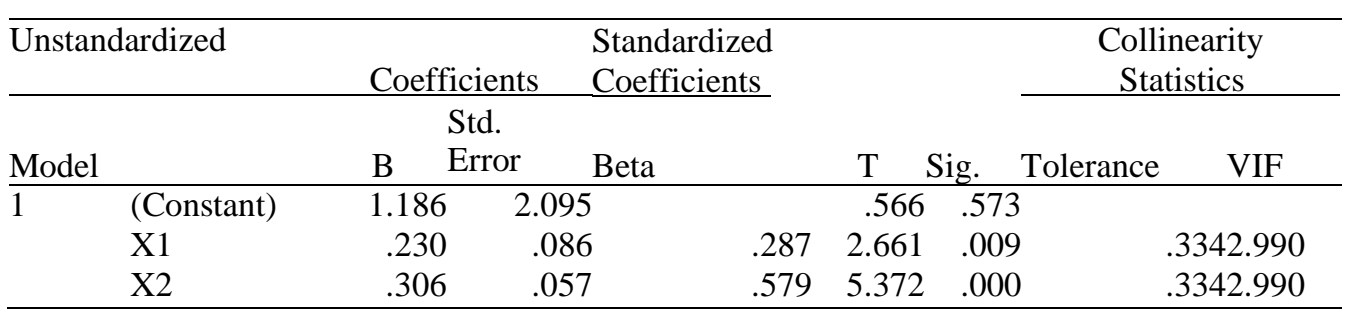

Table 3. Estimation and Testing of Regression Coefficients

Based on Table 3, the X1 variable obtained sig $=0.009$ and $\mathrm{t}$ arithmetic $=$ 2.661 while $\mathrm{t}$ table $=1.663$. Because the value of sig $<0.05$ and $\mathrm{t}$ arithmetic $>\mathrm{T}$ table means that there is a significant influence on the reputation variable (X1) on satisfaction (Y). It can be concluded that there is a significant influence of the independent variable reputation $\mathrm{X} 1$ on the dependent variable student satisfaction $\mathrm{Y}$ in the STDI Jakarta campus environment at a real level of 5\%. The regression coefficient is 0.230 , meaning that the average STDI student satisfaction will increase by 0.230 if the STDI reputation increases by one unit and the variable style of academic service quality remains. Student satisfaction can be created by providing several benefits including providing the best academic services to STDI students, this will provide recommendations from word of mouth that support STDI. Good academic services will have a positive impact on student satisfaction, similarly expressed by (Chandra, $\mathrm{Ng}, 2018$ ) through his findings that serious attention to the quality of services provided by universities and colleges is needed because the better the quality of services provided, the higher student satisfaction.

Furthermore, still from Table 3, the variable X2 obtained sig $=0.000$ and $\mathrm{t}$ arithmetic $=5.372$ while $\mathrm{t}$ table $=1.663$. Because the value of sig $<0.05$ and $\mathrm{t}$ arithmetic $>\mathrm{t}$ table means that there is a significant influence of academic service quality variables (X2) on student satisfaction (Y). It can be concluded that there is a significant effect of the independent variable academic service quality on the dependent variable of student satisfaction on the STDI Jakarta Campus at the 5\% level. The regression coefficient is 0.306 , meaning that the average student satisfaction will increase by 0.306 if the academic service quality increases by one unit and the variable reputation remains.

The quality of academic services is understood as the dimensions needed by academic service units in conducting an assessment and measurement. The dimensions of academic service are associated with satisfaction, namely 
reliability, responsiveness, confidence, empathy and tangibility. STDI academic services consist of academic services of lecturers and academic services of administrative employees. The level of satisfaction is in the satisfied category. Factors relating to lecturer professionalism, ease and convenience include lecturer professionalism, easy access to academic information and student comfort in the learning process having satisfied qualifications. Based on the satisfaction ranking, it is obtained that the most dominant factor influencing student satisfaction is the professionalism of lecturers about giving material clearly so that it is easy to understand.

Testing the joint influence of reputation and academic service quality on student satisfaction is recorded in Table 5. Obtained sig $=0,000$ and $\mathrm{F}$ arithmetic $=88,624$ while $\mathrm{F}$ table $=3.111$. Because the value of sig $\langle 0.05$ and $\mathrm{F}$ arithmetic $>$ $\mathrm{F}$ table, then reject Ho. That is, there is a significant influence of the independent variable reputation (X1) and academic service quality (X2) together on student satisfaction (Y) at the STDI Jakarta Campus at the 5\% level.

\begin{tabular}{llcccc}
\hline Model & Sum of Squares & Df & Mean Square & F & Sig. \\
\hline 1 & Regression & 273.531 & 2 & 136.76588 .624 & .000 \\
& Residual & 123.457 & 80 & 1.543 & \\
& Total & 396.988 & 82 & & \\
\hline
\end{tabular}

Table 4. Joint Testing with Variance Analysis

The level of confidence in the regression model that is built or the level of diversity of the dependent variable that can be explained by the independent variable is reflected in the coefficient of determination (R2). Based on the calculation results listed in Table 5, the coefficient of determination is obtained by 0.689 . That is, $69 \%$ of the average diversity of student satisfaction can be explained by the reputation and quality of academy services, while the remaining $31 \%$ is another factor that has not been included in the regression model. Other factors that may have an influence on student satisfaction and have not been included in the model are the STDI campus social environment, access roads and strategic location of the STDI campus and the suitability of costs with the facilities received.

\begin{tabular}{lllll}
\hline Model & $\mathrm{R}$ & R Square & $\begin{array}{l}\text { Adjusted R } \\
\text { Square }\end{array}$ & $\begin{array}{l}\text { Std. Error of the } \\
\text { Estimate }\end{array}$ \\
\hline 1 & $.830^{\mathrm{a}}$ & .689 & & .6811 .242
\end{tabular}

Table 5. Determination Coefficient Influence of Reputation and Quality of Academic Services on STDI Student Satisfaction

\section{Effect of Reputation on STDI Student Satisfaction}

Based on the $\mathrm{H} 1$ hypothesis, there is a significant effect of reputation on the satisfaction of STDI Jakarta students. The effect of X1 on Y of 0.230 (regression coefficient) means that the average STDI student satisfaction will increase by 0.230 if the STDI reputation increases by one unit and variable 
academic service quality remains. Whereas in Table 4 . Variable X1 obtained the value of $\operatorname{sig}=0.009$ and tcount $=2.661$ while $\mathrm{t}$ table $=1.661$. Because the sig value $<0.05$ and tcount $>\mathrm{T}$ table means that there is a significant influence the reputation variable $(\mathrm{X} 1)$ on the satisfaction variable $(\mathrm{Y})$. Thus it can be concluded that the $\mathrm{H} 1$ hypothesis is proven.

These results indicate that STDI's reputation in the eyes of students is good, because reputation is a picture that is in someone's mind. Reputation is also an intangible asset owned by a company. A favorable reputation includes emotional appeal, product and service and vision leadership. Employees of a company know the benefits of a positive and long-lasting company reputation and dangerous negative reputation, and understand their role to obtain and maintain a positive company reputation (Cravens and Oliver, 2006). Reputation can turn negative if it is not supported by actual abilities or circumstances. A good reputation influences the satisfaction of customers and employees of the company itself, increases customer loyalty and increases company growth and company survival. The results of quantitative hypothesis testing and the theory, strengthen the researchers to conclude that in this study reputation has a positive and significant influence on STDI student satisfaction.

\section{The effect of Academic Service Quality on STDI Student Satisfaction}

Based on the $\mathrm{H} 2$ hypothesis, there is a significant influence of academic service quality on the satisfaction of STDI Jakarta students. The influence of X2 on Y of 0.306 (regression coefficient) means that the average student satisfaction will increase by 0.306 if the academic service quality increases by one unit and the variable reputation remains. Being based on Table 4. Variable X2 obtained the value of sign $=0,000$ and tcount $=5,372$ while $t$ table $=1,663$. Because sig $<0.05$ and tcount $>t$ table means that there is a significant influence of academic service quality variable (X2) on student satisfaction variable (Y). Thus it can be concluded that the $\mathrm{H} 2$ hypothesis is proven.

These results indicate the quality of academic services at STDI Jakarta according to students considered good. Service quality is understood as the dimensions required by service units in conducting an assessment and measurement. Meanwhile, the quality of academic services is defined as a form of service carried out by academics to the maximum with all the advantages in order to meet the needs and expectations of students. Some dimensions that reflect the quality of service, especially in the service sector, include responsibility, reliability, responsiveness, assurance and empathy. Good quality services have effectiveness and efficiency in serving students so as to provide satisfaction to him. Based on the results of testing hypotheses and synthesis of existing theories, researchers provide conclusions that the quality of academic services has a positive effect on the satisfaction of STDI students (Yudana, Natajaya, 2013). In this case, the quality of academic services can answer the problems that arise in determining the services provided by STDI. 


\section{The effect of Reputation and Academic Service Quality on STDI Student Satisfaction}

Based on the hypothesis H3 showed a significant influence on the reputation and quality of academic services together the satisfaction of STDI Jakarta students. Based on table 5, obtained sig $=0,000$ and $\mathrm{F}$ count $=88,624$ while $\mathrm{F}$ table $=3,111$. This means that there is a significant influence of the independent variable reputation (X1) and academic service quality (X2) together on satisfaction (Y) at the STDI Jakarta Campus. So it can be concluded that the $\mathrm{H} 3$ hypothesis is proven.

The results above show that the reputation and quality of academic services at STDI Jakarta in the eyes of students is considered good. Based on the results of testing between the reputation and quality of academic services on STDI student satisfaction states there is a positive and significant influence. This explanation provides an understanding that the better the reputation and quality of academic services provided to students, the more they will increase on the STDI student satisfaction. This, according to the research (Chandra, $\mathrm{Ng}, 2018$ ), found that serious attention to the quality of services provided by universities and colleges is needed because the better the quality of services provided, the higher the satisfaction of students.

\section{CONCLUSION}

This research was conducted to determine the effect of reputation variables on student satisfaction variables. The influence of academic service quality variables on student satisfaction variables. The effect of the reputation variable and academic service quality variables together on student satisfaction variables at the the Interstudi Design College (STDI) Jakarta. Like the hypothesis proposed in the chapter above. Based on the results of hypothesis testing and discussion, it can be concluded that: firstly there is a significant effect between reputation on student satisfaction in STDI Jakarta, secondly there is a significant effect between the quality of academic services on student satisfaction at STDI Jakarta, and thirdly there is a significant effect $b$ effect etween reputation and quality academic services together on the satisfaction of STDI Jakarta students. With the limited time available so that this research results have not been maximized, it is necessary to continue it by the academics in the future to achieve better results. 


\section{ACKNOWLEDGMENT}

In compiling this journal, many parties have provided motivation, advice and support.

1. Mrs. Ike Martini, as Chair of the Interstudi Foundation, who has given study assignments to the Postgraduate Communication Studies Program (SIKOM), Interstudi.

2. Mr. Dr. Irwansyah, MA as Vice Chair I for Academic Affairs who has provided his support.

3. Mrs. Dr. Rosita Anggraini, M.Si., who provided guidance and direction for the completion of this journal writing.

4. Mrs. Dr. Poppy Ruliana, M.Si, who has helped provide direction and assistance.

5. My family and all those who have provided motivation and support and prayers I say many thanks, I hope to be a good charity.

\section{BIODATA}

Sudiharto, SE : Employee at Interstudi Communication College (STIKOM). Jakarta. as Head of Academic and Student Administration Section (BAAK) in 2019, and Head of General Administration (BAU) at Interstudies Design College (STDI, Jakarta (2011-2019).

Rosita Anggraini, Dr. M.Si : Posgraduate Interstudi,Indonesia

Irwansyah, Dr. MA : Communication Science Faculty of Sosial Science, University of Indonesia, Indonesia

\section{REFERENCES}

\section{Books}

Fombrun, C. J., \& Van Riel, C. B. M. (2007). Fame \& fortune: How the world's top companies develop winning reputations. Upper Saddle River, NJ: Pearson Education.

Kotler, P., \& Armstrong, G. (2010). Principles of marketing (13th ed.). Upper Saddle River, NJ: Prentice Hall.

Kotler, P. (2012). Marketing management/Philip Kotler, Kevin Lane Keller.

Pearson Education International, 817, 1.

Parasuraman, A., \& Zeithaml, V. A. (2012). Understanding and Improving Service Quality: A Literature Review and Research Agenda. In Handbook of Marketing (pp. 339-369). https://doi.org/10.4135/9781848608283.n15

Sarwono, J. (2012). Prosedur-Prosedur Populer Statistik untuk Mempermudah Riset Skripsi. Metamorfosis, 6(22), 104-121.

Sugiyono. (2012). Metode Penelitian Kuantitatif, Kualitatif dan R \& D.Bandung:Alfabeta. Metode Penelitian Kuantitatif, Kualitatif Dan R \& D.Bandung:Alfabeta., 117. https://doi.org/10.1017/CBO9781107415324.004 
SchIffman, L. G., \& Kanuk, L. L. (2010). Consumer Behavior 10th Edition. https://doi.org/10.1109/LPT.2004.842793

\section{Article or Chapter within a Book}

Calvo-Porral, C., Lévy-Mangin, J.-P., \& Novo-Corti, I. (2013). Perceived quality in higher education: an empirical study. Marketing Intelligence \& Planning, 31(6), 601-619. http://doi.org/10.1108/MIP-11-2012-0136

Blumler, J. G., Gurevitch, M., \& Katz, E. (1973). Uses and Gratifications Research. Public Opinion Quarterly, 37(4), 509. https://doi.org/10.1086/268109

\section{Article in a Scientific Journal}

Afridi, S. A., Khattak, A., \& Khan, A. (2016). Measurement of Service Quality Gap in The Selected Private Universities/Institutes of Peshawar Using SERVQUAL Model. City University Research Journal, 6(1), 61-69.

Retrieved from http://www.cityuniversity.edu.pk/curj/Journals/Journal/Jan 2016/artcile 05a.pdf

Andam, R., Montazeri, A., Feizi, S., \& Mehdizadeh, R. (2015). Providing a multidimensional measurement model for assessing quality of sport tourism services: Empirical evidence from sport conference as sport event tourism. Iranian Journal of Management Studies, 8(4), 607-629.

Arambewela, R., \& Hall, J. (2006). A Comparative Analysis of International Education Satisfaction Using SERVQUAL. Journal of Services Research, 6, 141-163. Retrieved from http://search.ebscohost.com/login.aspx?direct=true \&db=buh\&AN=225356 99\&site=ehostlive

Annamdevula, S., \& Bellamkonda, R. S. (2016b). The effects of service quality on student loyalty: the mediating role of student satisfaction. Journal of Service Management, 11(2), 446-462. http://doi.org/DOI 10.1108/JM2-04-2014-0031

Anderson, E. W., Fornell, C., \& Lehmann, D. R. (1994). Customer Satisfaction, Market Share, and Profitability: Findings from Sweden. Journal of Marketing, 58(3), 53. http://doi.org/10.2307/1252310

Bharwana, T. K., Bashir, D. M., \& Mohsin, M. (2013). Impact of Service Qua lity on Customers ' Satisfaction : A Study from Service Sector especially Private Colleges of Faisalabad, Punjab, Pakistan. International Journal of Scientific and Research Publications.

Babaei, D., Rahimian, H., Ahmad, A., Omar, Z., \& Idris, K. (2015). Ability mediation effects in the relationships between human resource practices and service quality. Iranian Journal of Management

Chandra, T., Ng, M., Chandra, S., \& Priyono. (2018). The effect of service quality on student satisfaction and student loyalty: An empirical study. Journal of Social Studies Education Research. https://doi.org/10.17499/jsser.12590

Cravens, K.S. and E.G. Oliver, 2006. Employees: The key link to corporate reputation management. Journal of Business Horizons, 49(4): 293-302 
Corneliu Munteanu, CiprianCeobanu, Claudia Boba^lca` and Oana Anton,2010.

An Analysis of Customer Satisfaction in a Higher Education Context, International Journal of Public Sector Management Vol. 23, No. 2, 2010, pp. 124-140. Emerald Group Publishing Limited 0951-3558 DOI $10.1108 / 09513551011022483$.

Dib, H., \& Alnazer, M. (2013). The impact of service quality on student satisfaction and behavioral consequences in higher education services. International Journal of Economy, Management and Social Sciences, 2(6), 285-290

Gruber, Thorsten; Stefan Fuß, Roediger Voss.(2010). Examining student satisfaction with higher education services: using a new measurement tool. International Journal of Public Sector Management,23 (2), pp. 105 - 123. DOI : 10.1108/09513551011022474

Kanakana, M. G. (2014). Assessing Service Quality in Higher Education using the SERVQUAL Tool. In International Conference on Industrial Engineering and operations Management (Vol. 1, pp. 68-74). Bali. Retrieved from http://iieom.org/ieom2014/pdfs/24.pdf

Kordshouli, H. R., Jafarpour, Y., \& Bouzanjani, A. A. (2016). An analysis of the pro-social behaviors of customers in response to the firms' service quality. Iranian Journal of Management Studies, 9(1), 21-41.

Saleem, S., Moosa, K., Imam, A., \& Ahmed Khan, R. (2017). Service Quality and Student Satisfaction: The Moderating Role of University Culture, Reputation and Price in Education Sector of Pakistan. Iranian Journal of Management Studies. https://doi.org/10.22059/ijms.2017.217335.672304

Semnani, B. L., Maymand, M. M., Dehkordi, L. F., \& Fard, R. S. (2015). Effect of Employee Branding on Customer Satisfaction, Favorable Reputation and Employee Satisfaction. International Journal of Asian Social Science. https://doi.org/10.18488/journal.1/2015.5.3/1.3.140.155

Wijaya, Tonny.(2011). Manajemen kualitas jasa: Desain Servqual, QFD, dan Kano disertai contoh Aplikasi dalam Kasus Penelitian. Yogyakarta, Universitas Atmajaya

Yudana,, Natajaya, (2013). Pengaruh Kualitas Pelayanan Akademik Terhadap Kepuasan Dan Loyalitas Mahasiswa Pada Sekolah Tinggi Pariwisata Nusa Dua

BALI. Jurnal Administrasi Pendidikan UNDIKSHA. Yousapronpaiboon, K. (2014). SERVQUAL: Measuring Higher Education

Service Quality in Thailand. Procedia - Social and Behavioral Sciences, 116, 1088-1095. http://doi.org/10.1016/j.sbspro.2014.01.350

\section{Thesis}

Khasani, I. (2013). The Influence of Corporate Identity On Sekolah Tinggi Desain Interstudi's Reputation (Sekolah Tiinggi Desain Interstudi). Retrieved from https://www.interstudi.edu/main 